\title{
Plant-based strategies aimed at expressing HIV antigens and neutralizing antibodies at high levels. Nef as a case study
}

\author{
Carla Marusic · Alessandro Vitale · Emanuela Pedrazzini - Marcello Donini • \\ Lorenzo Frigerio - Ralph Bock · Philip J. Dix • Matthew S. McCabe • \\ Michele Bellucci $\cdot$ Eugenio Benvenuto
}

Received: 11 November 2008/ Accepted: 6 January 2009/Published online: 25 January 2009

(C) Springer Science+Business Media B.V. 2009

\begin{abstract}
The first evidence that plants represent a valid, safe and cost-effective alternative to traditional expression systems for large-scale production of antigens and antibodies was described more than 10 years ago. Since then, considerable improvements have been made to increase the yield of plantproduced proteins. These include the use of signal sequences to target proteins to different cellular compartments, plastid transformation to achieve high
\end{abstract}

C. Marusic $(\bowtie) \cdot$ M. Donini · E. Benvenuto

Dipartimento BAS, Sezione Genetica e Genomica

Vegetale, ENEA, C.R. Casaccia, via Anguillarese 301, 00123 Rome, Italy

e-mail: carla.marusic@casaccia.enea.it

M. Donini

e-mail: marcello.donini@casaccia.enea.it

E. Benvenuto

e-mail: benvenutoe@casaccia.enea.it

A. Vitale $\cdot$ E. Pedrazzini

Istituto di Biologia e Biotecnologia Agraria,

Consiglio Nazionale delle Ricerche, via Bassini 15,

20133 Milan, Italy

A. Vitale

e-mail: vitale@ibba.cnr.it

E. Pedrazzini

e-mail: pedrazzini@ibba.cnr.it

L. Frigerio

Department of Biological Sciences, University of

Warwick, Coventry CV4 7AL, UK

e-mail: L.Frigerio@warwick.ac.uk transgene dosage, codon usage optimization to boost gene expression, and protein fusions to improve recombinant protein stability and accumulation. Thus, several HIV/SIV antigens and neutralizing anti-HIV antibodies have recently been successfully expressed in plants by stable nuclear or plastid transformation, and by transient expression systems based on plant virus vectors or Agrobacteriummediated infection. The current article gives an

\section{R. Bock}

Max-Planck-Institut für Molekulare Pflanzenphysiologie, Am Mühlenberg 1, 14476 Potsdam-Golm, Germany e-mail: RBock@mpimp-golm.mpg.de

\section{P. J. Dix · M. S. McCabe}

Department of Biology, National University of Ireland Maynooth, Maynooth, Co., Kildare, Ireland

P. J. Dix

e-mail: Phil.Dix@nuim.ie

M. S. McCabe

e-mail: matthew.s.mccabe@nuim.ie

M. Bellucci

Istituto di Genetica Vegetale, Consiglio Nazionale delle Ricerche, via della Madonna Alta 130, 06128 Perugia, Italy

e-mail: michele.bellucci@igv.cnr.it 
overview of plant expressed HIV antigens and antibodies and provides an account of the use of different strategies aimed at increasing the expression of the accessory multifunctional HIV-1 Nef protein in transgenic plants.

Keywords HIV · Nef - Multi-component vaccine . Plant made pharmaceuticals · Recombinant proteins . Heterologous expression systems

\section{Introduction}

As stated by the latest UNAIDS AIDS epidemic update (UNAIDS 2008 AIDS Epidemic update, http:// www.unaids.org), a total of 33.2 million people were living with HIV in 2007. Twenty-five years since the discovery of HIV, an effective vaccine is not yet available. Current efforts in vaccine design have been focused on subunit vaccines. The viral envelope (Env) was initially considered the best candidate as an inducer of neutralizing antibodies, but viral variability represents a barrier to obtain a broad immune response (Walker and Burton 2008; Fauci et al. 2008). This problem could be overcome by a polyvalent HIV vaccine, identifying constant domains on the viral envelope necessary for virus-cell interaction (Zolla-Pazner 2004) and through structural studies of HIV envelope spikes created by gp41 and gp120 proteins (Walker and Burton 2008).

A vaccine able to induce sterilizing immunity still remains a major challenge and modern vaccinology is directed to inducing broad humoral and cellular immune responses. Therefore, novel vaccines are becoming increasingly complex, with several being constituted by a combination of different recombinant antigens. Both structural (Env, Gag) and nonstructural HIV-1 gene products (Rev, Tat, Nef) are regarded as promising targets for multi-antigen vaccine development, able to induce durable antiviral immunity (Titti et al. 2007). Along with the development of subunit vaccines, antibodies with broad neutralizing activity against HIV-1 have been proposed for both prophylactic and therapeutic use (Trkola et al. 2005, 2008), although a major limitation to this treatment is represented by the necessity of a large-scale production system at low cost.
To achieve this aim the use of plants of agronomic relevance as bioreactors for large-scale production of biopharmaceuticals and vaccine components represents a safe and economical alternative to traditional production systems (Ma et al. 2003, 2005; Schillberg et al. 2005). A number of studies have already shown that structural and regulatory proteins of HIV or related viruses could be successfully expressed in plants by stable transformation or transient expression strategies (Table 1). Moreover, very recently different studies have been published on the over expression and characterization of plant-derived anti-HIV neutralizing antibodies (Table 2). In particular two mAbs, the anti-gp120 2G12 (Trkola et al. 1996) and the antigp41 2F5 (Conley et al. 1994), endowed with a broad HIV neutralising activity, have been extensively characterised. In the case of the $2 \mathrm{G} 12$ antibody, directing the expression to the seed endosperm of transgenic maize gave very promising results with production levels of $40-100 \mathrm{mg} / \mathrm{kg}$ dry seed weight (Ramessar et al. 2008; Rademacher et al. 2008). Moreover, both studies showed that the neutralising activity of the plant purified antibody was equivalent to or even better than that of the $\mathrm{CHO}$ (Chinese hamster ovary cells) derived 2G12. The same antibody was also transiently expressed in $N$. benthamiana by leaf agroinfiltration giving yields of $50 \mathrm{mg} / \mathrm{kg}$ of fresh biomass (Strasser et al. 2008). In the case of the mAb 2F5 expressed in transgenic tobacco plants it was shown that fusion of the heavy and light chains to an elastin-like peptide (ELP) repeat raised production yields mainly by enhancing protein stability, furthermore this strategy could simplify protein recovery and purification (Floss et al. 2008). The same antibody has been also expressed in transgenic tobacco cell suspension cultures yielding $6.4 \mathrm{mg} / \mathrm{kg}$ wet cell weight (Sack et al. 2007). In this case, although the plant derived 2F5 showed similar antigen binding activity compared to its $\mathrm{CHO}$ derived counterpart, HIV-1 neutralisation assays revealed a decreased efficiency. Taken together these results demonstrate the feasibility of expressing functional HIV-1 neutralising antibodies in plants at yields which could meet the requirements for a large-scale economical production.

The first examples reported in the literature of expression in plants of HIV components relate to sequences encoding epitopes of the viral Env (see Table 1 for references). In both env products, gp120 
Table 1 Plant expressed HIV-1 and SIV antigens
$T M V$ tobacco mosaic virus, $T B S V$ tomato bushy stunt virus, $P V X$ potato virus $\mathrm{X}$, $C P M V$ cowpea mosaic virus

\begin{tabular}{|c|c|c|c|}
\hline Protein/peptide & Plant & $\begin{array}{l}\text { Plant expression } \\
\text { system }\end{array}$ & Reference \\
\hline \multirow[t]{4}{*}{ Tat } & Spinach & TMV plant viral vector & Karasev et al. (2005) \\
\hline & Potato tuber & Nuclear transformation & Kim et al. (2004a) \\
\hline & Tomato & Nuclear transformation & Ramírez et al. (2007) \\
\hline & Tobacco & Nuclear transformation & Webster et al. (2005) \\
\hline \multirow[t]{3}{*}{ Nef } & Tobacco & Nuclear transformation & $\begin{array}{l}\text { Marusic et al. (2007), } \\
\text { Barbante et al. (2008), } \\
\text { de Virgilio et al. (2008) }\end{array}$ \\
\hline & Tobacco & Plastid transformation & $\begin{array}{l}\text { Zhou et al. (2008), } \\
\text { McCabe et al. (2008) }\end{array}$ \\
\hline & Tomato & Plastid transformation & Zhou et al. (2008) \\
\hline \multirow[t]{9}{*}{$\mathrm{p} 24$} & Tobacco & Nuclear transformation & Obregon et al. (2006) \\
\hline & N. benthamiana & TBSV plant viral vector & Zhang et al. (2000) \\
\hline & Tobacco & Nuclear transformation & Zhang et al. (2002) \\
\hline & N. benthamiana & TMV plant viral vector & Meyers et al. (2008) \\
\hline & N. benthamiana & Agroinfiltration & Meyers et al. (2008) \\
\hline & Tobacco & Nuclear transformation & Meyers et al. (2008) \\
\hline & Tobacco & Plastid transformation & Meyers et al. (2008) \\
\hline & Tobacco & Plastid transformation & $\begin{array}{l}\text { Zhou et al. (2008), } \\
\text { McCabe et al. (2008) }\end{array}$ \\
\hline & Tomato & Plastid transformation & Zhou et al. (2008) \\
\hline \multirow[t]{2}{*}{$\mathrm{p} 17 / \mathrm{p} 24$} & N. benthamiana & Agroinfiltration & Meyers et al. (2008) \\
\hline & Tobacco & Nuclear transformation & Meyers et al. (2008) \\
\hline \multirow[t]{3}{*}{ Pr55Gag } & N. benthamiana & TMV plant viral vector & Meyers et al. (2008) \\
\hline & N. benthamiana & Agroinfiltration & Meyers et al. (2008) \\
\hline & Tobacco & Nuclear transformation & Meyers et al. (2008) \\
\hline $\mathrm{SIV}_{\text {mac }} \mathrm{p} 27$ & Potato & Nuclear transformation & Kim et al. $(2004 b, c)$ \\
\hline \multirow[t]{4}{*}{ Env/gp120 V3 loop } & N. benthamiana & TMV plant viral vector & Yusibov et al. (1997) \\
\hline & Tobacco & TMV plant viral vector & $\begin{array}{c}\text { Sugiyama et al. (1995), } \\
\text { Beachy et al. (1996) }\end{array}$ \\
\hline & Potato & Nuclear transformation & Kim et al. (2004d) \\
\hline & N. benthamiana & TBSV plant viral vector & Joelson et al. 1997) \\
\hline Env/gp $130 \mathrm{SIV}_{\mathrm{mac}}$ & Corn kernel & Nuclear transformation & Horn et al. (2003) \\
\hline $\begin{array}{l}\text { Env/gp41 ELDKWA } \\
\text { epitope (662-667) }\end{array}$ & $N$. benthamiana & PVX plant viral vector & Marusic et al. (2001) \\
\hline P1 peptide (649-684) & N. benthamiana & Agroinfiltration & Matoba et al. (2004) \\
\hline Peptide (731-752) & Cowpea & $\begin{array}{l}\text { CPMV plant viral } \\
\text { vector }\end{array}$ & $\begin{array}{l}\text { Porta et al. (1994), McLain } \\
\text { et al. (1995, 1996), } \\
\text { Durrani et al. (1998), } \\
\text { McInerney et al. (1999) }\end{array}$ \\
\hline
\end{tabular}

and gp41 glycoproteins constant regions (epitopes) recognized by neutralizing antibodies have been identified (Zolla-Pazner 2004). Some of these protective epitopes (2F5, V3 loop, etc.) have been expressed, mainly fused to different plant virus capsid proteins, able to self-assemble and generate chimeric virus particles or chimeric virus like particles (VLP) (Table 1). Plant viruses and VLP were easily purified and their immunogenicity has been evaluated in animal models. Data have been reported about the capability of recombinant plant viruses to induce the production of antibodies able to neutralize 
Table 2 Plant expressed anti-HIV1 neutralizing antibodies

\begin{tabular}{|c|c|c|c|c|c|c|}
\hline Antibody & Species & Promoter & Compartment & $\begin{array}{l}\text { Plant expression } \\
\text { system }\end{array}$ & Yield & Reference \\
\hline \multirow[t]{3}{*}{$2 \mathrm{G} 12$} & Maize & $\begin{array}{c}\text { Endosperm } \\
\text { specific }\end{array}$ & Secretory & $\begin{array}{l}\text { Nuclear } \\
\quad \text { transformation }\end{array}$ & $\begin{array}{c}75 \mathrm{mg} / \mathrm{kg} \text { seed } \\
\text { dry weight }\end{array}$ & $\begin{array}{l}\text { Ramessar et al. } \\
\text { (2008) }\end{array}$ \\
\hline & Maize & $\begin{array}{c}\text { Endosperm } \\
\text { specific }\end{array}$ & ER retention & $\begin{array}{l}\text { Nuclear } \\
\quad \text { transformation }\end{array}$ & $\begin{array}{l}40 \mathrm{mg} / \mathrm{kg} \text { seed } \\
\text { dry weight }\end{array}$ & $\begin{array}{l}\text { Rademacher et al. } \\
\text { (2008) }\end{array}$ \\
\hline & N. benthamiana & CaMV 35S & Secretory & $\begin{array}{l}\text { Leaf } \\
\text { Agroinfiltration }\end{array}$ & $\begin{array}{c}50 \mathrm{mg} / \mathrm{kg} \text { fresh } \\
\text { leaf weight }\end{array}$ & $\begin{array}{l}\text { Strasser et al. } \\
\quad(2008)\end{array}$ \\
\hline \multirow[t]{2}{*}{$2 \mathrm{~F} 5$} & N. tabacum & CaMV 35S & ER retention & $\begin{array}{l}\text { Nuclear } \\
\quad \text { transformation }\end{array}$ & ND & $\begin{array}{c}\text { Floss et al. } \\
\text { (2008) }\end{array}$ \\
\hline & $\begin{array}{l}\text { N. tabacum cell } \\
\text { suspensions }\end{array}$ & CaMV 35S & ER retention & $\begin{array}{l}\text { Nuclear } \\
\quad \text { transformation }\end{array}$ & $\begin{array}{l}6.4 \mathrm{mg} / \mathrm{kg} \text { wet } \\
\text { cell weight }\end{array}$ & Sack et al. (2007) \\
\hline
\end{tabular}

CaMV cauliflower mosaic virus, $N D$ not determined

HIV in vitro (Yusibov et al. 1997; Marusic et al. 2001). Other studies demonstrated that Gag p17 and p24/p17 capsid proteins can be produced in plants using different expression strategies. A p24-immunoglobulin fusion molecule has been successfully expressed by nuclear transformation in tobacco plants and is able to elicit a T-cell and antibody immune response in mice (Obregon et al. 2006). Different results have been obtained with transiently expressed p17/p24 which proved non immunogenic in mice but was able to boost a humoral and T-cell response in mice primed with gag DNA vaccine (Meyers et al. 2008). Similarly, the HIV regulatory protein Tat produced in spinach did not induce a detectable antibody response in mice orally immunized with spinach leaves, but apparently mice were primed for the subsequent tat DNA immunization (Karasev et al. 2005). Nevertheless, Tat antigen expressed in tomato fruits was able to induce mucosal $\operatorname{IgAs}$ and serum IgGs with neutralizing activity after oral immunization in mice (Ramírez et al. 2007).

\section{Nef protein as a plant-made HIV vaccine component}

Among non-structural HIV-1 elements, the accessory protein Nef is considered a good candidate for the formulation of vaccines that combine both structural and functional viral components. Nef is expressed early during the viral life cycle and is necessary for both high viral load and disease progression. Moreover, nef genes are highly conserved in all primate lentiviruses (HIV-1, HIV-2, SIV). Experiments in a transgenic mouse model showed that Nef proteins of SIV and HIV are functionally interchangeable (Sinclair et al. 1997). In addition, data showed that patients classified as long-term non-progressors have alterations in the nef gene (Tobiume et al. 2002). Recently, promising studies on the generation of multi-component HIV vaccines, containing Nef, have been published, reporting the first clinical evaluation of a multi-component vaccine containing recombinant gp120 and Nef-Tat fusion proteins (Goepfert et al. 2007) and the effects of a multi-component genetic vaccine combining structural (Gag/Pol, Env) and regulatory (Rev, Tat, Nef) antigens in the SIVMacaca animal model (Voss et al. 2003; Maggiorella et al. 2007).

It has been demonstrated that nef gene yields two main products: a full-length form of $27 \mathrm{kDa}$ (p27) and a truncated form of $25 \mathrm{kDa}$ (p25), translated from a second start codon and lacking the first 18 amino acids. The p27 protein is post-translationally modified by the addition of a myristoyl group to the $\mathrm{N}$-terminus by which full-length Nef anchors to the cytosolic side of cellular membranes. The p25 was found in the cytosol, while the wild-type myristoylated p27 was mainly membrane associated (Yu and Felsted 1992). Nef contains several disordered regions, which cause difficulties in the resolution of its three-dimensional structure. However, the globular core domain and the N-terminal anchor domain have been characterised by X-ray crystallography, nuclear magnetic resonance (NMR) and NMR spectroscopy (Geyer et al. 1999; Geyer and Peterlin 
2001). The combination of data obtained from both functional and structural studies allowed the identification of sequence motifs involved in protein modification, signalling and trafficking (Geyer et al. 2001b). In general Nef affects protein trafficking in the host cells, down modulates cell-surface molecules such as CD4 and MHC-I, while enhancing virus infectivity and accelerating disease progression in both humans and primate animal models (Roeth and Collina 2006).

Both p27 and p25 isoforms have been expressed in different biological systems such as E. coli (Azad et al. 1994), yeast (Macreadie et al. 1998; Sirén et al. 2006), insect cells (Kohleisen et al. 1996), mammalian cells (Cooke et al. 1997) and plant cells (Marusic et al. 2007; Barbante et al. 2008; de Virgilio et al. 2008; Zhou et al. 2008; McCabe et al. 2008).

In the following paragraphs we will focus on the different biotechnological approaches developed by several different laboratories aimed at obtaining high accumulation of Nef in stable transgenics.

\section{Targeting HIV-1 Nef to different plant cell compartments}

Yield and stability of plant recombinant proteins are the main issues that must be addressed to develop competitive commercial products. Several approaches have been followed to express heterologous proteins at high levels and prevent protein degradation in plants (Benchabane et al. 2008). Subcellular targeting of recombinant proteins is one of the major research topics in the field of plant made pharmaceuticals. A number of strategies are now in place to direct proteins of interest to a specific cellular compartment (e.g., apoplast, plastid, mitochondrion, vacuole, endoplasmic reticulum) by the addition of specific targeting sequences (Streatfield 2007).

To achieve stable and high-level expression of Nef in transgenic plants a number of constructs were designed either for nuclear or plastid transformation, utilizing different signal or fusion peptides to direct the expression of the viral protein to either the cytosol or the secretory pathway. A schematic representation indicating the most successful Nef expression strategies and the relative yields are shown in Fig. 1 and will be reviewed in the following sections.

\section{Nef is stable in the cytosol of plant cells}

In the first study concerning plant recombinant Nef, a panel of constructs were designed to direct the expression of full-length $\mathrm{N}$-terminal myristoylated (p27), non-myristoylated (p27 mut) and truncated form (p25) of Nef, to either the cytosol or the secretory pathway (Marusic et al. 2007). In this work, all constructs were tested initially by tobacco protoplasts transfection followed by pulse chase analysis to rapidly establish the most promising strategy for protein expression in stable transgenic plants. All cytosolic forms of Nef (p25, p27 and p27 mut) appeared stable while small amounts of myristoylated protein (p27) were associated to the plant cell membrane. Constructs encoding p25 and p27 mut were used to generate transgenic tobacco plants. Quantitative ELISA revealed variable expression levels in independently transformed plants ranging between 0.18 and $0.7 \%$ of total soluble protein (TSP) with an observed average value of $0.5 \%$ as reported in Fig. 1. A small-scale purification was successfully attempted by IMAC chromatography taking advantage of the (His) 6 tag fused to the C-terminus of p27 mut (Marusic et al. 2007). The use of recombinant Nef lacking myristoylation as part of a multicomponent vaccine is considered advantageous at present (Peng et al. 2006). Indeed, deletion or mutagenesis of the $\mathrm{N}$-terminal myristoylation site has been shown to abrogate the capacity of Nef to down-regulate both MHC class I and CD4 cellsurface molecules (Peng and Robert-Guroff 2001), which normally prevent CTL-mediated lysis of HIV-1-primary infected cells (Collins et al. 1998).

\section{Attaching Nef to the cytosolic face of membranes as a strategy to improve accumulation}

A new, alternative strategy to improve p27 Nef accumulation in transgenic plants, recently developed by Barbante and colleagues (Barbante et al. 2008), involves anchoring the molecule to the cytosolic face of the endoplasmic reticulum (ER) membrane using the C-terminal portion of the mammalian ER isoform of cytochrome $b 5$ (ER $b 5$ ). ER $b 5$ belongs to the tailanchored (TA) protein family, which are bound to membranes by a C-terminally located hydrophobic sequence (Borgese et al. 2003). TA proteins do not 


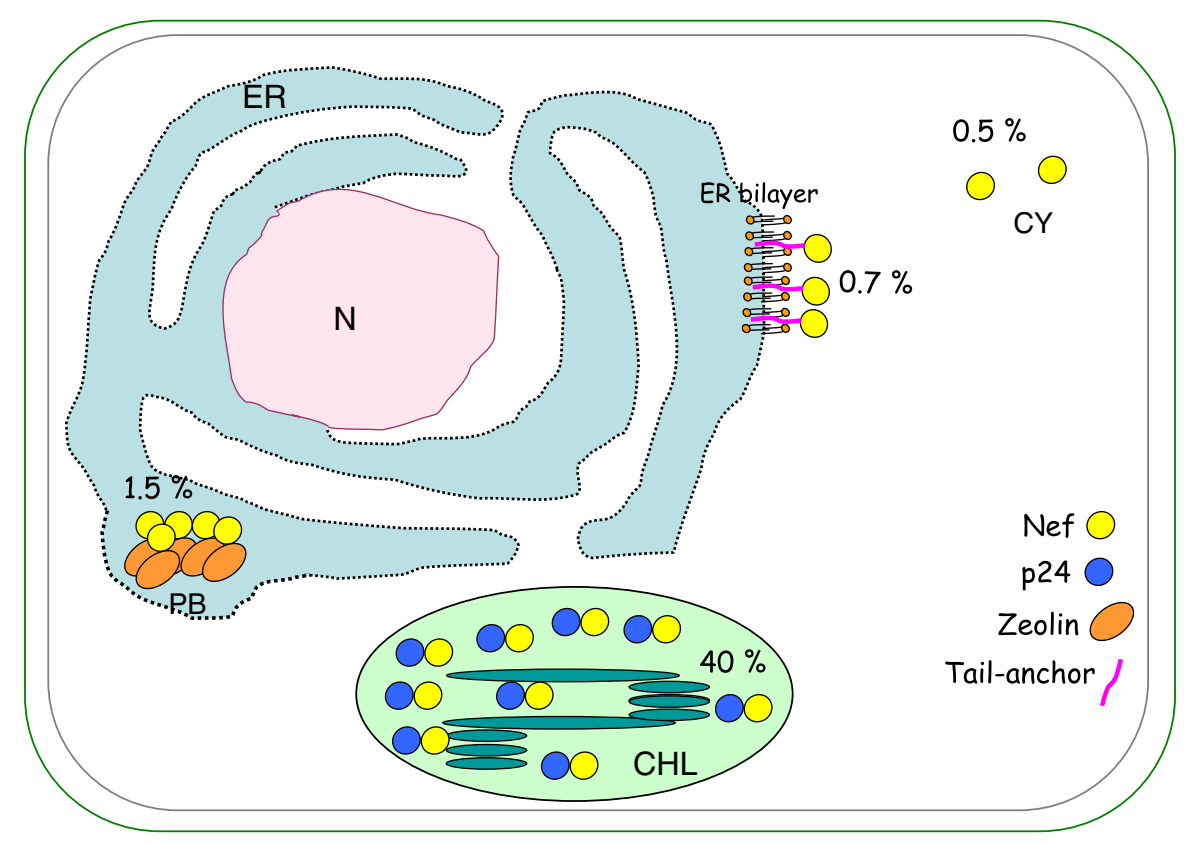

Fig. 1 Schematic representation of expression strategies used to accumulate HIV-1 Nef in plant cells. Nef fusion to the chimeric protein zeolin allows protein body formation $(P B)$ within the endoplasmic reticulum $(E R)$ lumen (de Virgilio et al. 2008); fusion to the C-terminal portion of the mammalian ER isoform of cytochrome b5 (tail-anchor) anchors recombinant

have an $\mathrm{N}$-terminal signal peptide and reach their destination post-translationally; their functional domains are exposed in the cytosol and only a short C-terminal segment is translocated (Borgese et al. 1993). Consistently, the resulting topology of the fusion molecule between Nef and the tail anchor of ER $b 5$ (Nef-TA) maintains the entire Nef portion in its ideal cytosolic environment.

The Nef polypeptide anchored to the cytosolic face of the ER membrane accumulated to higher levels (more than threefold) compared to its soluble cytosolic counterpart in all transgenic plants analyzed (Barbante et al. 2008). The values were $0.7 \%$ of TSPs for Nef-TA with very little variability within each group. Analysis of mRNA levels and pulse-chase experiments with radioactive amino acids indicated that the higher accumulation of Nef-TA is due to increased protein stability. These results confirm that the ER membrane is a convenient target location for chimeric membrane proteins because of its intrinsic plasticity and remodelling ability (Borgese et al. 2006), which is attuned to the amount of protein that enters the secretory pathway. In addition, being anchored to the ER protein to the cytosolic ER bilayer (Barbante et al. 2008); fusion to HIV-1 p24 and chloroplast $(\mathrm{CHL})$ transformation (Zhou et al. 2008; McCabe et al. 2008); Nef cytosolic expression (CY) (Marusic et al. 2007). Nucleus $(N)$. Protein expression levels are indicated and expressed as percentage of total soluble protein

membrane, the Nef protein is likely to be less susceptible to cytosolic degradation processes mediated by the ubiquitin/proteasome pathway.

The successful production of recombinant vaccines in transgenic plants also depends on the ease and efficiency of purification. Nef can be removed in vitro from its TA taking advantage of an engineered thrombin cleavage site (Barbante et al. 2008). This opens the way to a purification procedure involving microsome preparation and then solubilization of the molecule in a pure or nearly pure form by thrombin cleavage. This new strategy could be generally used for production purposes, when it is necessary to maintain the heterologous protein in the reducing environment of the cytosol and at the same time limit molecular interactions with the host cell machinery.

\section{Nef destiny in the secretory pathway: how to avoid quality control degradation}

The secretory pathway has been exploited extensively for the production of recombinant pharmaceuticals in 
plants. One of the reasons is that several classes of important pharmaceutical proteins are secretory proteins. The best known example is constituted by immunoglobulins, which fortunately are rather resistant to apoplastic proteases and therefore accumulate to high amounts (Hiatt et al. 1989; Ma et al. 1995). Further advantages reside in the finding that in all eukaryotic cells the ER, which is the port of entry to the secretory pathway, has low hydrolytic activity and that soluble proteins can easily be retained in this compartment by adding a signal peptide at the $\mathrm{N}$-terminus and the ER localization signals HDEL or KDEL at the C-terminus (Vitale and Denecke 1999). Moreover, the ER of plant cells can tolerate high accumulation of protein without compromising cell functions (Wandelt et al. 1992). For proteins that naturally reside in compartments other than the ER but have a short half-life, targeting to the ER has often increased accumulation (Doran 2006), although there are exceptions (Patel et al. 2007; Yang et al. 2007).

Transient expression of Nef in the secretory pathway of tobacco protoplasts, by the addition of the signal peptide (sp) of the PR1 protein (Denecke et al. 1990) to the N-terminal of both p25 and p27 Nef variants, resulted in marked instability during $5 \mathrm{~h}$ chase suggesting misfolding and degradation by ER quality control (Marusic et al. 2007). The ER is a folding environment different from the cytosol, mainly because it leads to the formation of disulfide bonds and $\mathrm{N}$-glycosylated proteins. These events have evolved to favour solubility, stability and in some cases biological activity of many secretory proteins, but when they occur on proteins that naturally reside in the cytosol and therefore are not disulfide-bonded, they obviously can change protein folding and have adverse effects. Experiments in which synthesis has been performed in the presence of the $\mathrm{N}$-glycosylation inhibitor tunicamycin proved that indeed Nef is glycosylated when inserted into the ER, but also showed that the inhibitor does not improve Nef stability in the secretory pathway (Marusic et al. 2007). It therefore seems likely that disulfide bonds are responsible for Nef misfolding.

It has been shown that in the cytosol Nef folding is a slow process: at the end of $1 \mathrm{~h}$ pulse-labelling, Nef Cys residues were still available for unproductive in vitro disulfide bond formation, a feature that was abolished by folding only upon $2 \mathrm{~h}$ chase. It is conceivable that such a relatively long-term availability of Cys residues for interactions leads to in vivo formation of disulfide bonds in the ER oxidizing environment, leading to misfolding (Barbante et al. 2008). Addition of KDEL was unable to rescue a structurally defective protein from degradation by ER quality control (Frigerio et al. 2001). This was also true in the case of Nef, where addition of KDEL was incapable of rescuing the protein from rapid degradation in transient expression (Barbante et al. 2008). This further indicates that targeting Nef to the lumen of the ER is likely to trigger its rapid degradation, possibly by quality control.

As an alternative strategy, de Virgilio et al. (2008) tried to promote the formation of protein bodies (PB) containing Nef. PB are plant-specific, ER located, insoluble polymers naturally formed by a number of cereal seed storage proteins and are held together by inter-chain disulfide bonds (Shewry et al. 1995). A significant amount of information is available regarding the maize prolamin $\gamma$-zein, which forms $\mathrm{PB}$ and accumulates to high amounts also when expressed in vegetative tissues (Coleman et al. 1996; Geli et al. 1994). It has been previously showed that a fragment of $\gamma$-zein, corresponding roughly to the $\mathrm{N}$-terminal half, is able to promote PB formation when fused to the vacuolar storage protein phaseolin in the chimeric protein zeolin (Mainieri et al. 2004). This leads to accumulation of zeolin up to $3.5 \%$ of tobacco leaf protein, roughly a tenfold improvement with respect to accumulation of phaseolin-KDEL (Mainieri et al. 2004). The first attempts to incorporate Nef into PB were however, disappointing: fusion of Nef to the same zein fragment used to construct zeolin, either in $\mathrm{N}$-terminal or C-terminal position, resulted in very poor accumulation in transgenic tobacco leaves (M. de Virgilio et al., unpublished data). Pulse-chase in the presence of the vesicular traffic inhibitor brefeldin A and analysis of the processing of glycans indicated that the chimeric proteins are degraded by ER quality control. Conversely, fusion of the entire zeolin sequence to Nef (zeolin-Nef) lead to PB formation and markedly improved accumulation, to about $1.5 \%$ of leaf protein, consistently in twenty independent transgenic plants that were analyzed (de Virgilio et al. 2008). Pulse-chase experiments and comparison of transcript levels indicated that the increased accumulation was exclusively due to a marked improvement in protein stability. Electron 
microscopy and subcellular fractionation showed that zeolin-Nef forms PB in the ER, even if these are smaller than those formed by zeolin.

The high instability of the fusions between Nef and the zein domain, and of Nef-KDEL, indicate that when a protein is recognized as structurally defective by the ER machinery, it is difficult to rescue it from quality control degradation. It is not known if the Nef-zein fusions are sorted for degradation before they have the possibility to form disulfide-linked polymers or after repeated unsuccessful attempts to polymerize, but these findings place the "approval" by the ER quality control machinery as a prerequisite for next steps in the synthesis of secretory proteins that lead either to polymerization and formation of $\mathrm{PB}$ or traffic along the secretory pathway to other destinations (de Virgilio et al. 2008; Vitale and Boston 2008). On the other hand, the successful accumulation of zeolin-Nef indicates that, when PB formation occurs, this rescues an heterologous unstable protein from degradation by quality control, markedly improving accumulation. Incorporation into insoluble PB can also provide an advantage in protein purification, but ultimately it will probably be necessary to remove the antigen from the appended sequence. In zeolin-Nef, a thrombin cleavage site was engineered between zeolin and the Nef sequence (de Virgilio et al. 2008); when the chimeric protein was solubilized with reducing agents, immunoprecipitated and treated in vitro with thrombin, Nef is released in a soluble form (M. de Virgilio and A. Vitale, unpublished data), indicating that, once released from zeolin, Nef is not grossly misfolded. However, further experiments are necessary to determine if the recombinant antigen can also be efficiently released from insoluble PB, thus making purification cost-effective.

\section{Chloroplast-produced Nef}

Plastid (chloroplast) transformation has emerged as an attractive tool for plant biotechnologists (Maliga 2004; Bock 2007; Koop et al. 2007). The major advantages of this technology are high-level foreign protein accumulation, ranging between two and more than $70 \%$ of TSP (Oey et al. 2008), and the absence of epigenetic effects (gene silencing and position effects). Moreover, the maternal plastid inheritance, which prevents pollen-mediated gene flow from the genetically modified plant to other plants, greatly increases transgene containment (Bock 2001; Ruf et al. 2007; Svab and Maliga 2007). Transgenic chloroplasts as bioreactors for the production of vaccines and biopharmaceuticals are very promising as indicated from a number of published studies (Daniell 2006).

Zhou and colleagues have explored the potential of the plastid transformation as an alternative tool to produce high levels of HIV-1 Nef and p24 antigens in plant cells (Zhou et al. 2008). For this purpose, a series of constructs were designed to express the p27 Nef protein either alone or as p24-Nef or Nef-p24 fusion proteins. As the analysis of the codon usage in the native $p 24$ and nef gene revealed significant differences from that in the (AT)-rich plastid genome, both genes were re-synthesized. All constructs were utilised to transform tobacco (cv. Petite Havana) plastids and the transplastomic (i.e., plastid-transformed) lines were purified to homoplasmy, the genetically stable state in which all wild-type plastid genomes are eliminated and a homogeneous population of transgenic plastid genomes is present (Bock 2001; Maliga 2004). Analysis of p24-Nef and Nefp24 fusion proteins showed that both can be expressed to relatively high levels in chloroplasts. Some lines harbouring nef as single gene, displayed a mutant phenotype with green and yellow sectors. nef mRNA and protein expression analysis showed that high levels of $n e f$ transcripts accumulated only in the yellow tissue while low amounts of nef mRNA were found in the green sectors. Consistent with this, when expression was analyzed at the protein level, high accumulation levels of Nef were seen only in the yellow plants (Zhou et al. 2008). Sequencing of the promoter region in several independent green and yellow lines showed that the phenotype was due to an homologous recombination event between a short and a full-length version of the tobacco plastid ribosomal RNA operon promoter. These results indicate that, if expressed to high levels, the Nef protein may be deleterious to the chloroplast by interfering with organellar functions (Zhou et al. 2008).

As the best results in terms of protein expression levels were obtained with the p24-Nef fusion protein, the correspondent gene was cloned in a new expression vector constructed to avoid recombination events. This construct was introduced into the 
tobacco and tomato plastid genomes. Transplastomic tobacco and tomato plants were analysed and protein accumulation was found to be close to $40 \%$ of the leaf's total protein and easily detectable by Coomassie staining. Transcript and protein accumulation were analysed in different ripening stage of tomato fruit and while green tomatoes accumulated the fusion protein to $2.5 \%$ of the total protein, the protein was not detectable in ripe fruits. However, the use of a green-fruited tomato variety, commercially available, seems the solution for the production of the antigens in an edible fruit (Zhou et al. 2008). It is also noteworthy that, despite the enormous expression levels obtained with the optimized p24-nef fusion gene, the transplastomic plants did not display the same strong phenotype as the nef plants, suggesting that fusion to p24 may alleviate the negative effects of Nef on chloroplast function.

As the tobacco cultivar generally used for plastid transformation is a relatively small variety (cv. "Petit Havana"), which produces only about 100-200 g of leaf material per plant, the yield of recombinant protein could be greatly increased if a high biomass cultivar was used. Philip Dix's group in Maynooth reports the production of high yields of HIV p27 Nef protein through plastid transformation of tobacco cv. Maryland Mammoth, a high biomass cultivar which produces about $1.5 \mathrm{~kg}$ leaf material per plant (M. S. McCabe et al., unpublished data).

All the transplastomic plants expressing Nef exhibited a yellow phenotype, as had previously been found in plants expressing the HIV p24 protein using an otherwise identical vector (McCabe et al. 2008). The cause of the pigment deficiency has not been explored further in these plants. It results in a reduction in growth rate but the plants still grow well, remain vigorous and reach flowering after about 120 days. Seedling tests revealed $100 \%$ yellow seedlings with no sign of segregation, supporting homoplasmy of these lines, which was confirmed by long-range PCR. Nef expression levels were estimated to be $300 \mu \mathrm{g} / \mathrm{g}$ fresh weight (equally $\sim 6 \%$ of TSP). The purification of Nef from Maryland Mammoth chloroplasts by ammonium sulphate precipitation followed by citric acid/sodium citrate treatment and cation exchange chromatography, a procedure previously used with success with HIV p24 (McCabe et al. 2008), was unsuccessful and the protein appeared unstable under these extraction conditions. Refinements in the extraction procedure are under investigation (M. S. McCabe et al., unpublished data). The tobacco cultivar Maryland Mammoth is a strong candidate for the production of commercial quantities of recombinant HIV proteins (including Nef), via chloroplast transformation.

\section{Conclusions}

The last AIDS epidemic update indicates that a vaccine able to induce neutralizing immunity is a priority. The goal of the HIV-1 vaccination should be to obtain an antibody barrier able to neutralize the virus preventing viral entry and to induce a durable cellular immune response overcoming strain-specific immunity (Walker and Burton 2008). In this context the design of a multi-antigen protein vaccine should include different viral components conserved among several strains. Studies concerning the generation of multi-component HIV vaccines, containing Nef, have been published (Goepfert et al. 2007; Voss et al. 2003; Maggiorella et al. 2007) and the results are very promising.

As the vast majority of people who need HIV vaccine live in developing countries, low-cost production should be considered an important issue together with the effectiveness of the vaccine design. In this context plants represent a cost-effective alternative to the expression systems frequently used to produce vaccine components (Ma et al. 2005; Schillberg et al. 2005).

In the present review we gave an overview of the different expression strategies developed to over produce HIV neutralizing antibodies and HIV antigens in plants, specifically focusing the attention on Nef protein.

Results obtained with the expression of HIV neutralising antibodies in transgenic plants are very promising, and indicate that plant-produced antibodies are generally comparable in terms of antigen binding and HIV neutralization activity to their CHOderived counterparts. Moreover, the high expression yields documented for the $2 \mathrm{G} 12$ antibody produced in maize seed endosperm make this plant expression platform particularly attractive and economically advantageous (Ramessar et al. 2008). Yet, a possible limitation to the applicability in therapy of plantderived $\mathrm{mAbs}$ could be represented by the difference in $\mathrm{N}$-glycan composition from their mammalian 
counterpart which could lead to immunogenicity problems (Jin et al. 2008). To address this limitation different strategies have been successfully adopted to modify the glycosylation pattern of plant derived mAbs which include the modulation of plant glycosylation using RNA interference (Cox et al. 2006; Strasser et al. 2008), the co-expression of specific human glycosyltransferases (Bakker et al. 2006; Fujiyama et al. 2007), or the exploitation of specific knockout transgenic lines that synthesize complex $\mathrm{N}$-glycans lacking immunogenic xylose and fucose epitopes (Schähs et al. 2007) and/or the retention of the immunoglobulin in the endoplasmic reticulum (ER) (Triguero et al. 2005).

In this work we particularly focused our attention on the different strategies attempted to express HIV-1 Nef in planta. The highest Nef accumulation has been obtained in chloroplasts of transplastomic vegetative tissue as fusion to $\mathrm{p} 24$ yielding up to $40 \%$ of TSP (Zhou et al. 2008), while expression of Nef alone in this organelle resulted in a much lower accumulation suggesting that protein degradation can be a limiting factor also in plastids. Attempts to express Nef alone in the cytosol demonstrated very low accumulation levels below $0.5 \%$ of TSP (Marusic et al. 2007), although it has been found that anchoring Nef to the cytosolic face of the ER by addition of a C-terminal tail-anchor domain can improve protein stability and accumulation (Barbante et al. 2008). The strategy of targeting Nef alone into the lumen of the ER proved deleterious for its stability, probably because of folding defects recognized by the quality control machinery. In this case Nef fusion to the vacuolar storage protein zeolin increases accumulation levels by preventing protein degradation in the secretory pathway (de Virgilio et al. 2008). The results are promising, however, they do not equal those obtained in leaf chloroplasts.

In conclusion, although absolute comparisons in terms of protein yield between the different expression strategies discussed cannot be made, general considerations can be drawn from the results obtained in this collaborative research. The expression of Nef protein alone in different cell compartments tended to result in low accumulation levels. Conversely, the fusion to stabilizing protein components appears to be at the moment the most promising approach to enhancing yields, although in this case efficient extraction and purification of the antigen still has to be demonstrated.
In the light of these results, as the immunogenicity of a number of HIV-1 antigens produced in plants has been already reported, future work will move on from optimisation of expression and aim at testing the immunological properties of plant expressed Nef to verify the possibility of including it with other HIV antigens, already expressed in plants, in a potential HIV vaccine.

Acknowledgments We are grateful to Julian K.-C. Ma and George P. Lomonossoff for critical revision of the manuscript and useful suggestions. This work was supported by a grant from the European Union (FP6 Integrated Project 'PharmaPlanta'; www.Pharma-Planta.org).

\section{References}

Azad AA, Failla P, Lucantoni A, Bentley J, Mardon C, Wolfe A, Fuller K, Hewish D, Sengupta S, Sankovich S, Grgacic E, McPhee D, Macreadie I (1994) Large-scale production and characterization of recombinant human immunodeficiency virus type 1 Nef. J Gen Virol 75:651-655. doi: 10.1099/0022-1317-75-3-651

Bakker H, Rouwendal GJ, Karnoup AS, Florack DE, Stoopen GM, Helsper JP, van Ree R, van Die I, Bosch D (2006) An antibody produced in tobacco expressing a hybrid beta-1,4-galactosyltransferase is essentially devoid of plant carbohydrate epitopes. Proc Natl Acad Sci USA 103:7577-7582. doi:10.1073/pnas.0600879103

Barbante A, Irons S, Hawes C, Frigerio L, Vitale A, Pedrazzini E (2008) Anchorage to the cytosolic face of the ER membrane: anew strategy to stabilize a cytosolic recombinant antigen in plants. Plant Biotechnol J 6:560-575. doi:10.1111/j.1467-7652.2008.00342.x

Beachy RN, Fitchen JH, Hein MB (1996) Use of plant viruses for delivery of vaccine epitopes. Ann N Y Acad Sci 792:43-49. doi:10.1111/j.1749-6632.1996.tb32489.x

Benchabane M, Goulet C, Rivard D, Faye L, Gomord V, Michaud D (2008) Preventing unintended proteolysis in plant protein biofactories. Plant Biotechnol J 6:633-648. doi:10.1111/j.1467-7652.2008.00344.x

Bock R (2001) Transgenic chloroplasts in basic research and plant biotechnology. J Mol Biol 312:425-438. doi: 10.1006/jmbi.2001.4960

Bock R (2007) Plastid biotechnology: prospects for herbicide and insect resistance, metabolic engineering and molecular farming. Curr Opin Biotechnol 18:100-106. doi: 10.1016/j.copbio.2006.12.001

Borgese N, D’Arrigo A, De Silvestris M, Pietrini G (1993) $\mathrm{NADH}$-cytochrome $b 5$ reductase and cytochrome $b 5$ isoforms as models for the study of post-translational targeting to the endoplasmic reticulum. FEBS Lett 325:70-75. doi:10.1016/0014-5793(93)81416-W

Borgese N, Colombo S, Pedrazzini E (2003) The tale of tailanchored proteins: coming from the cytosol and looking for a membrane. J Cell Biol 161:1013-1019. doi:10.1083/ jcb.200303069 
Borgese N, Francolini M, Snapp E (2006) Endoplasmic reticulum architecture: structures in flux. Curr Opin Cell Biol 18:358-364. doi:10.1016/j.ceb.2006.06.008

Coleman CE, Herman EM, Takasaki K, Larkins BA (1996) The maize $\gamma$-zein sequesters $\alpha$-zein and stabilizes its accumulation in protein bodies of transgenic tobacco endosperm. Plant Cell 8:2335-2345

Collins KL, Chen BK, Kalams SA, Walker BD, Baltimore D (1998) HIV-1 Nef protein protects infected primary cells against killing by cytotoxic $\mathrm{T}$ lymphocytes. Nature 391:397-401. doi:10.1038/34929

Conley AJ, Kessler JA 2nd, Boots LJ, Tung JS, Arnold BA, Keller PM, Shaw AR, Emini EA (1994) Neutralization of divergent human immunodeficiency virus type 1 variants and primary isolates by IAM-41-2F5, an anti-gp41 human monoclonal antibody. Proc Natl Acad Sci USA 91:33483352. doi:10.1073/pnas.91.8.3348

Cooke SJ, Coates K, Barton $\mathrm{CH}$, Biggs TE, Barrett SJ, Cochrane A, Oliver K, McKeating JA, Harris MP, Mann DA (1997) Regulated expression vectors demonstrate cell-type-specific sensitivity to human immunodeficiency virus type 1 Nef-induced cytostasis. J Gen Virol 78: 381-392

Cox KM, Sterling JD, Regan JT, Gasdaska JR, Frantz KK, Peele CG, Black A, Passmore D, Moldovan-Loomis C, Srinivasan M, Cuison S, Cardarelli PM, Dickey LF (2006) Glycan optimization of a human monoclonal antibody in the aquatic plant Lemna minor. Nat Biotechnol 24:15911597. doi: $10.1038 / \mathrm{nbt} 1260$

Daniell H (2006) Production of biopharmaceuticals and vaccines in plants via the chloroplast genome. Biotechnol J 1:1071-1079. doi:10.1002/biot.200600145

de Virgilio M, De Marchis F, Bellucci M, Mainieri D, Rossi M, Benvenuto E, Arcioni S, Vitale A (2008) The human immunodeficiency virus antigen Nef forms protein bodies in leaves of transgenic tobacco when fused to zeolin. J Exp Bot 59:2815-2829. doi:10.1093/jxb/ern143

Denecke J, Botterman J, Deblaere R (1990) Protein secretion in plant cells can occur via a default pathway. Plant Cell 2:51-59

Doran PM (2006) Foreign protein degradation and instability in plants and plant tissue cultures. Trends Biotechnol 24:426-432. doi:10.1016/j.tibtech.2006.06.012

Durrani Z, McInerney TL, McLain L, Jones T, Bellaby T, Brennan FR, Dimmock NJ (1998) Intranasal immunization with a plant virus expressing a peptide from HIV-1 gp41 stimulates better mucosal and systemic HIV-1-specific IgA and IgG than oral immunization. J Immunol Methods 220:93-103. doi:10.1016/S0022-1759 (98)00145-8

Fauci AS, Johnston MI, Dieffenbach CW, Burton DR, Hammer SM, Hoxie JA, Martin M, Overbaugh J, Watkins DI, Mahmoud A, Greene WC (2008) HIV vaccine research: the way forward. Science 321:530-532. doi:10.1126/ science. 1161000

Floss DM, Sack M, Stadlmann J, Rademacher T, Scheller J, Stöger E, Fischer R, Conrad U (2008) Biochemical and functional characterization of anti-HIV antibody-ELP fusion proteins from transgenic plants. Plant Biotechnol J 6:379-391. doi:10.1111/j.1467-7652.2008.00326.x
Frigerio L, Pastres A, Prada A, Vitale A (2001) Influence of KDEL on the fate of trimeric or assembly-defective phaseolin: selective use of an alternative route to vacuoles. Plant Cell 13:1109-1126

Fujiyama K, Furukawa A, Katsura A, Misaki R, Omasa T, Seki T (2007) Production of mouse monoclonal antibody with galactose-extended sugar chain by suspension cultured tobacco BY2 cells expressing human beta $(1,4)$-galactosyltransferase. Biochem Biophys Res Commun 358:8591. doi:10.1016/j.bbrc.2007.04.054

Geli MI, Torren M, Ludevid D (1994) Two structural domains mediate two sequential events in $\gamma$-zein targeting: protein endoplasmic reticulum retention and protein body formation. Plant Cell 6:1911-1922

Geyer M, Peterlin BM (2001) Domain assembly, surface accessibility and sequence conservation in full length HIV-1 Nef. FEBS Lett 496:91-95. doi:10.1016/S00145793(01)02394-8

Geyer M, Munte CE, Schorr J, Kellner R, Kalbitzer HR (1999) Structure of the anchor-domain of myristoylated and nonmyristoylated HIV-1 Nef protein. J Mol Biol 289:123138. doi:10.1006/jmbi.1999.2740

Geyer M, Fackler OT, Peterlin BM (2001) Structure-function relationships in HIV-1 Nef. EMBO Rep 2:580-585. doi: 10.1093/embo-reports/kve141

Goepfert PA, Tomaras GD, Horton H, Montefiori D, Ferrari G, Deers M, Voss G, Koutsoukos M, Pedneault L, Vandepapeliere P, McElrath MJ, Spearman P, Fuchs JD, Koblin BA, Blattner WA, Frey S, Baden LR, Harro C, Evans T (2007) NIAID HIV vaccine trials network. Durable HIV-1 antibody and T-cell responses elicited by an adjuvanted multi-protein recombinant vaccine in uninfected human volunteers. Vaccine 25:510-518. doi:10.1016/j.vaccine. 2006.07.050

Hiatt A, Cafferkey R, Bowdish K (1989) Production of antibodies in transgenic plants. Nature 342:76-78. doi: 10.1038/342076a0

Horn ME, Pappu KM, Bailey MR, Clough RC, Barker M, Jilka JM, Howard JA, Streatfield SJ (2003) Advantageous features of plant-based systems for the development of HIV vaccines. J Drug Target 11:539-545. doi:10.1080/ 10611860410001669992

Jin C, Altmann F, Strasser R, Mach L, Schähs M, Kunert R, Rademacher T, Glössl J, Steinkellner H (2008) A plantderived human monoclonal antibody induces an anti-carbohydrate immune response in rabbits. Glycobiology 18:235-241. doi:10.1093/glycob/cwm137

Joelson T, Akerblom L, Oxelfelt P, Strandberg B, Tomenius K, Morris TJ (1997) Presentation of a foreign peptide on the surface of tomato bushy stunt virus. J Gen Virol 78:12131217

Karasev AV, Foulke S, Wellens C, Rich A, Shon KJ, Zwierzynski I, Hone D, Koprowski H, Reitz M (2005) Plant based HIV-1 vaccine candidate: tat protein produced in spinach. Vaccine 23:1875-1880. doi:10.1016/j.vaccine. 2004.11.021

Kim TG, Ruprecht R, Langridge WH (2004a) Synthesis and assembly of a cholera toxin B subunit SHIV 89.6p Tat fusion protein in transgenic potato. Protein Expr Purif 35:313-319. doi:10.1016/j.pep.2004.02.007 
Kim TG, Ruprecht R, Langridge WH (2004b) SIVmac Gag p27 capsid protein gene expression in potato. Protein Expr Purif 36:312-317. doi:10.1016/j.pep.2004.04.015

Kim TG, Gruber A, Ruprecht RM, Langridge WH (2004c) Synthesis and assembly of SIVmac Gag p27 capsid protein cholera toxin $\mathrm{B}$ subunit fusion protein in transgenic potato. Mol Biotechnol 28:33-40. doi:10.1385/MB: 28:1:33

Kim TG, Gruber A, Langridge WH (2004d) HIV-1 gp120 V3 cholera toxin B subunit fusion gene expression in transgenic potato. Protein Expr Purif 37:196-202. doi:10.1016/ j.pep.2004.04.014

Kohleisen B, Gaedigk-Nitschko K, Ohlmann M, Götz E, Ostolaza H, Goni FM, Erfle V (1996) Heparin-binding capacity of the HIV-1 NEF-protein allows one-step purification and biochemical characterization. $\mathrm{J}$ Virol Methods 60:89-101. doi:10.1016/0166-0934(96)02049-6

Koop HU, Herz S, Golds TJ, Nickelsen J (2007) The genetic transformation of plastids. Top Curr Genet 19:457-510. doi:10.1007/4735_2007_0225

Ma JK, Hiatt A, Hein M, Vine ND, Wang F, Stabila P, van Dolleweerd C, Mostov K, Lehner T (1995) Generation and assembly of secretory antibodies in plants. Science 268:716-719. doi:10.1126/science.7732380

Ma JK, Drake PM, Christou P (2003) The production of recombinant pharmaceutical proteins in plants. Nat Rev Genet 4:794-805. doi:10.1038/nrg1177

Ma JK, Barros E, Bock R, Christou P, Dale PJ, Dix PJ, Fischer R, Irwin J, Mahoney R, Pezzotti M, Schillberg S, Sparrow P, Stoger E, Twyman RM (2005) Molecular farming for new drugs and vaccines. Current perspectives on the production of pharmaceuticals in transgenic plants. EMBO Rep 6:593-599. doi:10.1038/sj.embor.7400470

Macreadie IG, Fernley R, Castelli LA, Lucantoni A, White J, Azad A (1998) Expression of HIV-1 nef in yeast causes membrane perturbation and release of the myristylated Nef protein. J Biomed Sci 5:203-210

Maggiorella MT, Sernicola L, Crostarosa F, Belli R, PavoneCossut MR, Macchia I, Farcomeni S, Tenner-Racz K, Racz P, Ensoli B, Titti F (2007) Multiprotein genetic vaccine in the SIV-Macaca animal model: a promising approach to generate sterilizing immunity to HIV infection. J Med Primatol 36:180-194. doi:10.1111/j.16000684.2007.00236.x

Mainieri D, Rossi M, Archinti M, Bellucci M, De Marchis F, Vavassori S, Pompa A, Arcioni S, Vitale A (2004) Zeolin A new recombinant storage protein constructed using maize $\gamma$-zein and bean phaseolin. Plant Physiol 136:34473456. doi:10.1104/pp.104.046409

Maliga P (2004) Plastid transformation in higher plants. Annu Rev Plant Biol 55:289-313. doi:10.1146/annurev.arplant. 55.031903.141633

Marusic C, Rizza P, Lattanzi L, Mancini C, Spada M, Belardelli F, Benvenuto E, Capone I (2001) Chimeric plant virus particles as immunogens for inducing murine and human immune responses against human immunodeficiency virus type 1. J Virol 75:8434-8439. doi:10.1128/ JVI.75.18.8434-8439.2001

Marusic C, Nuttall J, Buriani G, Lico C, Lombardi R, Baschieri S, Benvenuto E, Frigerio L (2007) Expression, intracellular targeting and purification of HIV Nef variants in tobacco cells. BMC Biotechnol 7:12. doi:10.1186/ 1472-6750-7-12

Matoba N, Magérus A, Geyer BC, Zhang Y, Muralidharan M, Alfsen A, Arntzen CJ, Bomsel M, Mor TS (2004) A mucosally targeted subunit vaccine candidate eliciting HIV-1 transcytosis-blocking Abs. Proc Natl Acad Sci USA 101:13584-13589. doi:10.1073/pnas.0405297101

McCabe MS, Klaas M, Gonzalez-Rabade N, Poage M, BadilloCorona J, Zhou F, Karcher D, Bock R, Gray JC, Dix PJ (2008) Plastid transformation of high biomass tobacco variety Maryland Mammoth for production of HIV-1 p24 antigen. Plant Biotech J 6:914-929. doi:10.1111/j.14677652.2008.00365.x

McInerney TL, Brennan FR, Jones TD, Dimmock NJ (1999) Analysis of the ability of five adjuvants to enhance immune responses to a chimeric plant virus displaying an HIV-1 peptide. Vaccine 17:1359-1368. doi:10.1016/ S0264-410X(98)00388-0

McLain L, Porta C, Lomonossoff GP, Durrani Z, Dimmock NJ (1995) Human immunodeficiency virus type 1-neutralizing antibodies raised to a glycoprotein 41 peptide expressed on the surface of a plant virus. AIDS Res Hum Retroviruses 11:327-334

McLain L, Durrani Z, Wisniewski LA, Porta C, Lomonossoff GP, Dimmock NJ (1996) Stimulation of neutralizing antibodies to human immunodeficiency virus type 1 in three strains of mice immunized with a 22 amino acid peptide of gp41 expressed on the surface of a plant virus. Vaccine 14:799-810. doi:10.1016/0264-410X(95) 00229-T

Meyers A, Chakauya E, Shephard E, Tanzer FL, Maclean J, Lynch A, Williamson AL, Rybicki EP (2008) Expression of HIV-1 antigens in plants as potential subunit vaccines. BMC Biotechnol 8:53. doi:10.1186/1472-6750-8-53

Obregon P, Chargelegue D, Drake PM, Prada A, Nuttall J, Frigerio L, Ma JK (2006) HIV-1 p24-immunoglobulin fusion molecule: a new strategy for plant-based protein production. Plant Biotechnol J 4:195-207. doi:10.1111/ j.1467-7652.2005.00171.x

Oey M, Lohse M, Kreikemeyer B, Bock R (2008) Exhaustion of the chloroplast protein synthesis capacity by massive expression of a highly stable protein antibiotic. Plant $\mathrm{J}$. doi:10.1111/j.1365-313X.2008.03702.x

Patel J, Zhu H, Menassa R, Gyenis L, Richman A, Brandle J (2007) Elastin-like polypeptide fusions enhance the accumulation of recombinant proteins in tobacco leaves. Transgenic Res 16:239-249. doi:10.1007/s11248-0069026-2

Peng B, Robert-Guroff M (2001) Deletion of N-terminal myristoylation site of HIV Nef abrogates both MHC-1 and CD4 down-regulation. Immunol Lett 78:195-200. doi: 10.1016/S0165-2478(01)00250-4

Peng B, Voltan R, Cristillo AD, Alvord WG, Davis-Warren A, Zhou Q, Murthy KK, Robert-Guroff M (2006) Replicating Ad-recombinants encoding non-myristoylated rather than wild-type HIV Nef elicit enhanced cellular immunity. AIDS 20:2149-2157. doi:10.1097/QAD.0b013 e32801086ee

Porta C, Spall VE, Loveland J, Johnson JE, Barker PJ, Lomonossoff GP (1994) Development of cowpea mosaic virus as a high-yielding system for the presentation of 
foreign peptides. Virology 202:949-955. doi:10.1006/ viro.1994.1417

Rademacher T, Sack M, Arcalis E, Stadlmann J, Balzer S, Altmann F, Quendler H, Stiegler G, Kunert R, Fischer R, Stoger E (2008) Recombinant antibody 2 G12 produced in maize endosperm efficiently neutralizes HIV-1 and contains predominantly single-GlcNAc N-glycans. Plant Biotechnol J 6:189-201. doi:10.1111/j.1467-7652.2007. 00306. $\mathrm{x}$

Ramessar K, Rademacher T, Sack M, Stadlmann J, Platis D, Stiegler G, Labrou N, Altmann F, Ma J, Stöger E, Capell T, Christou P (2008) Cost-effective production of a vaginal protein microbicide to prevent HIV transmission. Proc Natl Acad Sci USA 105:3727-3732. doi:10.1073/ pnas.0708841104

Ramírez YJ, Tasciotti E, Gutierrez-Ortega A, Donayre Torres AJ, Olivera Flores MT, Giacca M, Gómez Lim MA (2007) Fruit-specific expression of the human immunodeficiency virus type 1 tat gene in tomato plants and its immunogenic potential in mice. Clin Vaccine Immunol 6:685-692. doi:10.1128/CVI.00028-07

Roeth JF, Collina KL (2006) Human immunodeficiency virus type 1 Nef: adapting to intracellular trafficking pathways. Microbiol Mol Biol Rev 70:548-563. doi:10.1128/ MMBR.00042-05

Ruf S, Karcher D, Bock R (2007) Determining the transgene containment level provided by chloroplast transformation. Proc Natl Acad Sci USA 104:6998-7002. doi:10.1073/ pnas.0700008104

Sack M, Paetz A, Kunert R, Bomble M, Hesse F, Stiegler G, Fischer R, Katinger H, Stoeger E, Rademacher T (2007) Functional analysis of the broadly neutralizing human antiHIV-1 antibody 2 F5 produced in transgenic BY-2 suspension cultures. FASEB J 21:1655-1664. doi:10.1096/ fj.06-5863com

Schähs M, Strasser R, Stadlmann J, Kunert R, Rademacher T, Steinkellner H (2007) Production of a monoclonal antibody in plants with a humanized $N$-glycosylation pattern. Plant Biotechnol J 5:657-663. doi:10.1111/j.1467-7652. 2007.00273.x

Schillberg S, Twyman RM, Fischer R (2005) Opportunities for recombinant antigen and antibody expression in transgenic plants-technology assessment. Vaccine 23:17641769. doi:10.1016/j.vaccine.2004.11.002

Shewry PR, Napier JA, Tatham AS (1995) Seed storage proteins: structures and biosynthesis. Plant Cell 7:945-956

Sinclair E, Barbosa P, Feinberg MB (1997) The nef gene products of both simian and human immunodeficiency viruses enhance virus infectivity and are functionally interchangeable. J Virol 71:3641-3651

Sirén N, Weegar J, Dahlbacka J, Kalkkinen N, Fagervik K, Leisola M, vonWeymarn N (2006) Production of recombinant HIV-1 Nef (negative factor) protein using Pichia pastoris and a low-temperature fed-batch strategy. Biotechnol Appl Biochem 44:151-158. doi:10.1042/BA2 0060001

Strasser R, Stadlmann J, Schähs M, Stiegler G, Quendler H, Mach L, Glössl J, Weterings K, Pabst M, Steinkellner H (2008) Generation of glyco-engineered Nicotiana benthamiana for the production of monoclonal antibodies with a homogeneous human-like $\mathrm{N}$-glycan structure. Plant
Biotechnol J 6:392-402. doi:10.1111/j.1467-7652.2008. 00330.x

Streatfield SJ (2007) Approaches to achieve high-level heterologous protein production in plants. Plant Biotechnol J 5:2-15. doi:10.1111/j.1467-7652.2006.00216.x

Sugiyama Y, Hamamoto H, Takemoto S, Watanabe Y, Okada Y (1995) Systemic production of foreign peptides on the particle surface of tobacco mosaic virus. FEBS Lett 359:247-250. doi:10.1016/0014-5793(95)00054-D

Svab Z, Maliga P (2007) Exceptional transmission of plastids and mitochondria from the transplastomic pollen parent and its impact on transgene containment. Proc Natl Acad Sci USA 104:7003-7008. doi:10.1073/pnas.0700063104

Titti F, Cafaro A, Ferrantelli F, Tripiciano A, Moretti S, Caputo A, Gavioli R, Ensoli F, Robert-Guroff M, Barnett S, Ensoli B (2007) Problems and emerging approaches in HIV/ AIDS vaccine development. Expert Opin Emerg Drugs 12:23-48. doi:10.1517/14728214.12.1.23

Tobiume M, Takahoko M, Yamada T, Tatsumi M, Iwamoto A, Matsuda M (2002) Inefficient enhancement of viral infectivity and CD4 downregulation by human immunodeficiency virus type 1 Nef from Japanese long-term nonprogressors. J Virol 76:5959-5965. doi:10.1128/JVI. 76.12.5959-5965.2002

Triguero A, Cabrera G, Cremata JA, Yuen CT, Wheeler J, Ramírez NI (2005) Plant-derived mouse IgG monoclonal antibody fused to KDEL endoplasmic reticulum-retention signal is $N$-glycosylated homogeneously throughout the plant with mostly high-mannose-type $N$-glycans. Plant Biotechnol J 3:449-457. doi:10.1111/j.1467-7652.2005. 00137.x

Trkola A, Purtscher M, Muster T, Ballaun C, Buchacher A, Sullivan N, Srinivasan K, Sodroski J, Moore JP, Katinger H (1996) Human monoclonal antibody 2G12 defines a distinctive neutralization epitope on the gp120 glycoprotein of human immunodeficiency virus type 1 . J Virol 70:1100-1108

Trkola A, Kuster H, Rusert P, Joos B, Fischer M, Leemann C, Manrique A, Huber M, Rehr M, Oxenius A, Weber R, Stiegler G, Vcelar B, Katinger H, Aceto L, Günthard HF (2005) Delay of HIV-1 rebound after cessation of antiretroviral therapy through passive transfer of human neutralizing antibodies. Nat Med 11:615-622. doi: $10.1038 / \mathrm{nm} 1244$

Trkola A, Kuster H, Rusert P, von Wyl V, Leemann C, Weber R, Stiegler G, Katinger H, Joos B, Günthard HF (2008) In vivo efficacy of human immunodeficiency virus neutralizing antibodies: estimates for protective titers. J Virol 82:1591-1599. doi:10.1128/JVI.01792-07

Vitale A, Boston RS (2008) Endoplasmic reticulum quality control and the unfolded protein response: insights from plants. Traffic 9:1581-1588. doi:10.1111/j.1600-0854.2008. 00780.x

Vitale A, Denecke J (1999) The endoplasmic reticulum-gateway of the secretory pathway. Plant Cell 11:615-628

Voss G, Manson K, Montefiori D, Watkins DI, Heeney J, Wyand M, Cohen J, Bruck C (2003) Prevention of disease induced by a partially heterologous AIDS virus in rhesus monkeys by using an adjuvanted multicomponent protein vaccine. J Virol 77:1049-1058. doi:10.1128/JVI.77.2. 1049-1058.2003 
Walker BD, Burton DR (2008) Toward an AIDS vaccine. Science 320:760-764. doi:10.1126/science.1152622

Wandelt CI, Khan MR, Craig S, Schroeder HE, Spencer D, Higgins TJ (1992) Vicilin with carboxy-terminal KDEL is retained in the endoplasmic reticulum and accumulates to high levels in the leaves of transgenic plants. Plant $\mathrm{J}$ 2:181-192

Webster DE, Thomas MC, Pickering R, Whyte A, Dry IB, Gorry PR, Wesselingh SL (2005) Is there a role for plantmade vaccines in the prevention of HIV/AIDS? Immunol Cell Biol 83:239-247. doi:10.1111/j.1440-1711.2005. 01341.x

Yang L, Suzuki K, Hirose S, Wakasa Y, Takaiwa F (2007) Development of transgenic rice seed accumulating a major Japanese cedar pollen allergen (Cry j 1) structurally disrupted for oral immunotherapy. Plant Biotechnol $\mathrm{J}$ 5:815-826. doi:10.1111/j.1467-7652.2007.00287.x

Yu G, Felsted RL (1992) Effect of myristoylation on p27 nef subcellular distribution and suppression of HIV-LTR transcription. Virology 187:46-55. doi:10.1016/0042-6822 (92)90293-X
Yusibov V, Modelska A, Steplewski K, Agadjanyan M, Weiner D, Hooper DC, Koprowski H (1997) Antigens produced in plants by infection with chimeric plant viruses immunize against rabies virus and HIV-1. Proc Natl Acad Sci USA 94:5784-5788. doi:10.1073/pnas.94. 11.5784

Zhang G, Leung C, Murdin L, Rovinski B, White KA (2000) In planta expression of HIV-1 p24 protein using an RNA plant virus-based expression vector. Mol Biotechnol 14:99-107. doi:10.1385/MB:14:2:99

Zhang G, Rodrigues L, Rovinski B, White KA (2002) Production of HIV-1 p24 protein in transgenic tobacco plants. Mol Biotechnol 20:131-136. doi:10.1385/MB:20:2:131

Zhou F, Badillo-Corona JA, Karcher D, Gonzalez-Rabade N, Piepenburg K, Borchers A-MI, Maloney AP, Kavanagh TA, Gray JC, Bock R (2008) High-level expression of HIV antigens from the tobacco and tomato plastid genomes. Plant Biotechnol J 6:897-913. doi:10.1111/j.14677652.2008.00356.x

Zolla-Pazner S (2004) Identifying epitopes of HIV-1 that induce protective antibodies. Nat Rev Immunol 4:199-210 